УДК 343.98

DOI https://doi.org/10.32837/pyuv.v0i2(27).218

\author{
В. М. Щербанюк \\ ад’юнкт заочної форми навчання \\ кафедри криміналістики та судової медицини \\ Національної академії внутрішніх справ
}

\title{
МІСЦЕ ВЧИНЕННЯ ЗЛОЧИНУ ЯК ЕЛЕМЕНТ КРИМІНАЛІСТИЧНОЇ ХАРАКТЕРИСТИКИ ВТЕЧІ З МІСЦЬ ПОЗБАВЛЕННЯ ВОЛІ АБО З-ПІД ВАРТИ
}

Однією з обставин, яка відповідно до статті 91 КПК України підлягає обов'язковому доказуванню під час розслідування кожного кримінального правопорушення, є місце вчинення злочину. Також місце вчинення злочину як об'єктивна категорія знаходить своє відображення у процесуальних документах (зокрема, у протоколі огляду місця подіі), зазначається судом у мотивувальній частині вироку (п. 2 ч. 3 ст. 374 КПК України), а відповідно до ст. 218 КПК України місце виявлення ознак злочину, місце закінчення злочину та місце настання наслідків злочину зумовлюють вибір місця проведення досудового розслідування [1].

Крім того, встановлення місця вчинення злочину може мати значення для правильної кваліфікації протиправного діяння, адже в окремих статтях особливої частини КК України ця обставина зазначається як конструктивна ознака об'єктивної сторони складу злочину, в зв'язку з чим установлення того факту, що злочин, вчинений в іншому, відмінному від вказаного у диспозиції статті КК України, місці означає або відсутність взагалі в діянні складу злочину, або призводить до необхідності кваліфікації злочину за іншими статтями Кримінального кодексу України [2, с. 44].

Проблеми місця вчинення злочину висвітлювалися, зокрема, у працях К.Л. Акоєва, Ю.В. Бауліна, Р.С. Бєлкіна, М.Й. Коржанського, Є.В. Лащука, А.А. Музики, Т.В. Родіонова, А.В. Савченко, B.I. Тютюгіна, M.I. Хавронюка та багатьох інших. Однак наразі більшість питань, пов'язаних із вивченням місця вчинення злочину як елементу криміналістичної характеристики злочину, залишаються невирішеними.

Метою нашої статті є дослідження місця вчинення злочину як елементу криміналістичної характеристики втечі з місць позбавлення волі або 3-під варти.

3 криміналістичної точки зору місце вчинення злочину є місцем концентрації максимальної кількості матеріальних слідів злочину, джерелом отримання початкової об'єктивної інформації про подію злочину, встановлення якої дозволяє визначити кількість осіб, які вчинили злочин, напрямок їх руху, встановити пособників вчинення злочину, правильно та ефективно застосувати службово-розшукову собаку з метою організації переслідування злочинців, а також висунути та перевірити обгрунтовані розшукові версії [3, с. 45].

У Великому юридичному словнику місце злочину визначається як місце, на якому відбулося діяння, значиме у криміналістичному та кримінально-правовому відношенні [4, с. 369]. Крім того, місце вчинення злочину є факультативною ознакою об'єктивної сторони злочину, що характеризує настання у просторі юридичного факту передбаченого кримінальним законом певного суспільно небезпечного діяння [5, с. 156].

Більш широке визначення цього поняття пропонує К.Л. Акоєв, який зазначає, що місце вчинення злочину - це частина соціального простору, де фізичною особою вчиняється конкретне суспільно небезпечне діяння шляхом протиправного впливу на суб'єктів суспільних відносин, взаємозв'язок між ними, а також соціальні цінності, предмети матеріального світу, ідеологічні цінності, з приводу яких виникають ці суспільні відносини, тобто на об'єкт злочину На підтвердження своєї думки, вчений наводить приклад, вказуючи, що дійсно, місця позбавлення волі - це місця відбування покарання, яким притаманна соціально-правова характеристика, адже вони є установами, котрі реалізовують один з видів державного примусу, що на підставі закону застосовується до осіб, які вчинили злочини [6, с. 22].

Відповідно до диспозиції статті 392 КК України кримінально-караною є втеча з місць позбавлення волі або з-під варти, яка завжди пов'язана із залишенням особою певного місця - меж охоронюваної території установи виконання покарань або установи для попереднього ув'язнення. Водночас втеча може бути вчинена не тільки безпосередньо з цих установ, а й з-під конвою, коли підозрюваний, обвинувачений або засуджений доставляється до слідчо-судових органів, перебуває під охороною в автомобілі або поїзді, кабінеті слідчого, залі суду, виконує роботи за межами території установи виконання покарань тощо [7].

Результати проведеного нами дослідження показали, що місцями вчинення втечі засуджених та осіб, які перебувають під вартою, є: установа виконання покарань $(46,2 \%)$, установа для попереднього ув'язнення $(21,4 \%)$, приміщення та територія органу Національної поліції (4,8\%), при- 
міщення та територія суду $(8,3 \%)$, автотранспорт $(9,0 \%)$, поїзд $(1,1 \%)$, інше (контрагентські об’єкти, лікувальні заклади тощо) $(9,2 \%)$.

У статті 11 Кримінально-виконавчого кодексу України зазначається, що установами виконання покарань є: арештні доми, кримінально-виконавчі установи, спеціальні виховні установи (виховні колонії), а також в окремих випадках слідчі ізолятори.

Арештні доми виконують покарання у виді арешту. В арештних домах тримаються повнолітні особи, а також неповнолітні, яким на момент постановлення вироку виповнилося шістнадцять років і які засуджені за злочини невеликої тяжкості.

Кримінально-виконавчі установи поділяються на кримінально-виконавчі установи відкритого типу (виправні центри) і кримінально-виконавчі установи закритого типу (виправні колонії).

Виправні колонії поділяються на колонії мінімального, середнього і максимального рівнів безпеки.

Виправні колонії виконують покарання у виді позбавлення волі на певний строк, довічного позбавлення волі.

Слідчі ізолятори виконують функції виправних колоній мінімального рівня безпеки iз загальними умовами тримання i виправних колоній середнього рівня безпеки стосовно засуджених, які залишені для роботи з господарського обслуговування, адже осіб, вперше засуджених до позбавлення волі за злочини невеликої або середньої тяжкості чи тяжкі злочини, може бути за їхньою згодою залишено у слідчому ізоляторі чи направлено у виправну колонію максимального рівня безпеки для роботи з господарського обслуговування.

Виховні колонії виконують покарання у виді позбавлення волі на певний строк стосовно засуджених неповнолітніх [8].

Установи виконання покарань, звідки вчинили втечу засуджені особи, розподілилися таким чином: виправні колонії мінімального рівня безпеки 3 полегшеними умовами тримання - 11,3\% (від загальної кількості втеч з місць позбавлення волі або з-під варти); виправні колонії мінімального рівня безпеки із загальними умовами тримання - 16,6\%; виправні колонії середнього рівня безпеки - $10,7 \%$; виправні колонії максимального рівня безпеки - $2,1 \%$; слідчі ізолятори $-4,3 \%$; виховні колонії - 1,2\%.

За результатами проведеного аналізу можна зробити висновок, що найбільший відсоток втеч здійснюється 3 виправних колоній мінімального та середнього рівня безпеки, що, на нашу думку, зумовлюється встановленим у вказаних установах режимом відбування покарання, а також можливістю перебування засуджених на дільницях соціальної реабілітації, які створюються лише у виправних колоніях мінімального і середнього рівня безпеки.

У дільницях соціальної реабілітації під наглядом тримаються вперше засуджені до позбавлення волі за злочини, вчинені з необережності, злочини невеликої та середньої тяжкості, а також засуджені, переведені з дільниці ресоціалізації. При цьому засуджені мають ряд додаткових прав, зокрема: у вільний від роботи час від підйому до відбою користуються правом вільного пересування в межах території дільниці; з дозволу адміністрації колонії можуть пересуватися без нагляду поза територією дільниці, але в межах населеного пункту, якщо це необхідно за характером виконуваної ними роботи або у зв'язку з навчанням; можуть носити цивільний одяг, мати при собі портативні персональні комп'ютери та аксесуари до них, гроші та цінні речі, користуватися грошима без обмеження тощо [8].

Установами для тримання осіб, щодо яких як запобіжний захід обрано тримання під вартою, відповідно до Закону України «Про попереднє ув'язнення», є слідчі ізолятори Державної кримінально-виконавчої служби України, гауптвахти Військової служби правопорядку у Збройних Силах України. В окремих випадках, що визначаються потребою в проведенні слідчих дій, вказані особи можуть перебувати в ізоляторах тимчасового тримання [9].

Вивченням кримінальних проваджень встановлено, що місця втечі з установ для попереднього ув'язнення розподілилися таким чином: слідчі ізолятори - 11,9\% (від загальної кількості втеч 3 місць позбавлення волі або з-під варти); гауптвахти Військової служби правопорядку в ЗСУ - 2,1\% ; ізолятори тимчасового тримання $-7,4 \%$.

Крім того, слід зауважити, що втеча з під-варти може бути вчинена також із приміщень органів Національної поліції під час проведення слідчих (розшукових дій), із залів судових засідань, куди особа доставлена для розгляду питання про продовження запобіжного заходу, а також з приміщень лікувальних закладів, де їй надається медична допомога.

Загалом вибір місця втечі з установ виконання покарань визначається способом та часом вчинення втечі, а також іншими обставинами, зокрема, відсутністю належного нагляду, недоліками в наявній системі охорони, порою року, погодними умовами. Традиційно місцем вчинення втечі називають житлову чи промислову зону, виробничі об'єкти, медичну частину, ділянки соціальної реабілітації тощо [10, с. 112-113]. Однак з криміналістичної точки зору більш інформативним $€$ встановлення конкретного місця втечі - ділянки місцевості, що має свої межі і на якій безпосередньо були вчинені дії, спрямовані на реалізацію злочинного умислу. Це зазвичай місця, які не 
проглядаються 3 різних напрямків, неосвітлені або погано освітлені, малолюдні, недостатньо оснащені інженерно-технічними засобами охорони і нагляду ділянки периметру основного загородження, що дозволяє засудженому залишити установу виконання покарань чи установу для попереднього ув'язнення з найменшою вірогідністю бути поміченим [11, с. 6$]$.

Також слід звернути увагу і на те, що втечі 3 місць позбавлення волі або з-під варти вчиняються не лише з приміщень вищевказаних установ, але й під час конвоювання чи етапування засуджених чи взятих під варту осіб за допомогою залізничного чи автомобільного транспорту. У таких випадках місцем вчинення злочину буде вважатися транспортний засіб, з якого здійснено втечу (службовий автомобіль, вагон поїзду). Також наявні випадки, коли втеча відбувається під час посадки в автомобіль чи поїзд, зокрема, на проїзній частині вулиці, у приміщенні чи на пероні вокзалу тощо. У такому разі місцем вчинення злочину слід вважати частину території, обмежену лінією охорони, а також ділянку місцевості вздовж маршруту руху особи, яка здійснює втечу, протяжність котрого визначається слідчим, виходячи з обстановки вчинення злочину.

Підводячи підсумок, варто зазначити, що під час розслідування втечі з місць позбавлення волі або з-під варти необхідно встановлювати не лише безпосереднє місце вчинення злочину, але й місця, де відбувалися дії, спрямовані на підготовку до вчинення злочину, де залишилися сліди злочину, а також місце приховання засобів і знарядь вчинення злочину та місце затримання злочинця. Вказане сприяє отриманню максимально повної об'єктивної інформації про вчинений злочин, виявленню та вилученню слідів злочину та багато в чому визначає хід подальшого розслідування. Окрім того, виокремлення найбільш поширених місць вчинення втечі дозволяє вжити комплекс превентивних заходів, спрямованих на недопущення втеч в подальшому, покращити організацію та якість несення служби працівниками установ виконання покарань, установ для попереднього ув'язнення та конвойних підрозділів.

\section{Jimepamypa}

1. Кримінальний процесуальний кодекс України від 13.04.2012 № 4651-VI URL: https://zakon.rada.gov. ua/laws/show/4651-17.

2. Родіонова Т.В. Місце вчинення злочину за кримінальним правом України : дис. ... канд. юрид. наук : 12.00.08 / Держ. НДІ М-ва внутр. справ України. Київ, 2018. 247 c.

3. Грязева Н.В. Методика расследования побегов из мест лишения свободы : дисс. ... канд. юрид. наук : 12.00.09. Москва, 2014. 234 с.

4. Большой юридический словарь / под ред. А.Я. Сухарева, В.Д. Зорькина, В.Е. Крутских. Москва : Инфра-М, 1997.790 с.
5. Музика А.А., Лащук Є.В. Предмет злочину: теоретичні основи пізнання : монографія. Київ : ПАЛИВОДА А. В., 2011. 192 с.

6. Акоев К.Л. Место совершения преступления и его уголовно-правовое значение : учебное пособие. Ставрополь : Сервисшкола, 2000. 176 с.

7. Стаття 393. Втеча з місця позбавлення волі або з-під варти. Мего-Інфо - Юридичний портал № 1 : вебсайт. URL : http://mego.info/матеріал/стаття-393втеча-з-місця-позбавлення-волі-або-з-під-варти (дата звернення: 08.07.2019).

8. Кримінально-виконавчий кодекс України від 11.07.2003 № 1129-IV URL : https://zakon.rada.gov.ua/ laws/show/1129-15.

9. Про попереднє ув'язнення : Закон України від 30 черв. 1993 р. № 3352-XII. URL: https://zakon.rada. gov.ua/laws/show/3352-12 (дата звернення: 07.07.2018)

10. Ямашкин А.С. Методика расследования побегов из мест лишения свободы : дисс. ... канд. юрид. наук : 12.00.09. Саранск, 2010. $256 \mathrm{c.}$

11. Пелецкий В.О. Обстановка совершения преступления как элемент криминалистической характеристики самовольного оставления воинской части или места службы. Проблемы законности. 2011. С. 3-10.

\section{Анотація}

Щербанюк В. М. Місце вчинення злочину як елемент криміналістичної характеристики втечі з місць позбавлення волі або з-під варти. - Стаття.

У статті проаналізовано різноманітні точки зору вчених на поняття «місце вчинення злочину». Визначено основні місця вчинення втечі засуджених та осіб, щодо яких обрано запобіжний захід у вигляді тримання під вартою.

Розглянуто такі місця здійснення втечі засуджених та осіб, які перебувають під вартою, як установи виконання покарань, установи для попереднього ув'язнення, приміщення та територія органів Національної поліції, приміщення та територія суду, куди особа доставлена для розгляду питання про продовження запобіжного заходу, автотранспорт, поїзди, контрагентські об'єкти, лікувальні заклади тощо. Зазначається, що з криміналістичної точки зору інформативним $є$ встановлення конкретного місця втечі - ділянки місцевості, що має свої межі і на якій безпосередньо були вчинені дії, спрямовані на реалізацію злочинного умислу.

За результатами проведеного дослідження зроблено висновок, що найбільший відсоток втеч здійснюється з виправних колоній мінімального та середнього рівня безпеки, що, на думку автора, зумовлюється встановленим у вказаних установах режимом відбування покарання, а також можливістю перебування засуджених на дільницях соціальної реабілітації, які створюються лише у виправних колоніях мінімального і середнього рівня безпеки.

Доведено, що вибір місця втечі визначається способом та часом вчинення втечі, а також іншими обставинами, зокрема, відсутністю належного нагляду, недоліками в наявній системі охорони, порою року, погодними умовами. Традиційно місцем вчинення втечі називають житлову чи промислову зону, виробничі об'єкти, медичну частину, ділянки соціальної реабілітації.

Підкреслюється, що під час розслідування втечі з місць позбавлення волі або з-під варти необхідно встановлювати не лише безпосереднє місце вчинення злочину, але й місце, де відбувалися дії, спрямовані на підготовку до вчинення злочину, де залишилися сліди злочину, місце приховання засобів і знарядь вчи- 
нення злочину та місце затримання злочинця. Вказане дозволяє отримати максимально повну об'єктивну інформацію про вчинений злочин, виявити та вилучити сліди злочину та багато в чому визначає хід подальшого розслідування.

Ключові слова: місце вчинення злочину, втеча 3 місць позбавлення волі або з-під варти, установа виконання покарань, установа для попереднього ув'язнення, слідчий ізолятор.

\section{Summary}

Shcherbaniuk $V$. M. The place of the crime as an element of forensic character of escape from prison or from custody. - Article.

The article analyzes various viewpoints of scientists on the concept of "crime scene". The main places of escape of the convicted persons and persons for whom a pre-trial detention in the form of detention was selected were identified.

The following places of escape of convicts and persons in custody, such as penitentiary institutions, pre-trial detention facilities, premises and territory of the National Police bodies, premises and territory of the court where the person was brought to consider the issue of continuation of pre-trial detention, motor transport are considered , trains, counterparty facilities, medical facilities and more.

It is noted that, from a criminalistic point of view, it is informative to establish a specific place of escape - a section of a locality that has its limits and on which the actions aimed at realizing a criminal intent were directly committed.

According to the results of the research, it is concluded that the largest percentage of escapes is carried out from the minimum and medium security correctional colonies, which, in the author's opinion, is conditioned by the regime of punishment established in the specified institutions, as well as the possibility of finding prisoners at social rehabilitation sites, which are created only in minimum and medium security correctional colonies.

It is proved that the choice of escape location is determined by the method and time of the escape, as well as by other circumstances, such as lack of proper supervision, deficiencies in the existing security system, time of year, weather conditions. Traditionally, the place of escape is called a residential or industrial area, manufacturing facilities, medical unit, social rehabilitation sites.

It is emphasized that not only the immediate crime scene but also the places where actions were taken to prepare for the crime, where the traces of the crime remained, as well as the place of concealment, should be established during the investigation of the escape from the places of detention or from custody. and the instrument of the crime and the place where the offender was detained. The above helps to obtain the most complete objective information about the crime, to identify and remove the traces of the crime, and largely determines the course of further investigation.

Key words: place of the crime, escape from prison or from custody, penitentiary institution, pre-trial detention facility, remand prison. 